\title{
Chain-End Effect for Intermediate Water Formation of Poly(2- Methoxyethyl Acrylate)
}

\author{
S. Nishimura*a (iD) \\ T. Uedab (iD) \\ D. Murakami ${ }^{a, b}$ (iD \\ M. Tanaka*a,b (D) \\ ${ }^{a}$ Institute for Materials Chemistry and Engineering, Kyushu University, 744, Moto-oka, \\ Nishi-ku, Fukuoka 819-0395, Japan \\ ${ }^{b}$ Graduate School of Engineering, Kyushu University, 744, Moto-oka, Nishi-ku, \\ Fukuoka 819-0395, Japan \\ shinnosuke_nishimura@ms.ifoc.kyushu-u.ac.jp; \\ masaru_tanaka@ms.ifoc.kyushu-u.ac.jp
}

Received: 07.01.2021

Accepted after revision: 08.03.2021

DOI: 10.1055/a-1441-8239; Art ID: om-21-0001sc

License terms: CC

(C) 2021. The Author(s). This is an open access article published by Thieme under the terms of the Creative Commons Attribution License, permitting unrestricted use, distribution, and reproduction so long as the original work is properly cited. (https:// creativecommons.org/licenses/by/4.0/)

Abstract Intermediate water (IW), which is formed not only by biocompatible polymers such as poly(2-methoxyethyl acrylate) (PMEA), but also by biomacromolecules, plays a key role in determining the biocompatibility of synthetic polymers. In this study, we compare the well-defined linear and cyclic PMEA using differential scanning calorimetry and atomic force microscopy. This study aims to clarify the role of the chain-end effect in IW formation to establish design guidelines for biomaterials.

Key words intermediate water, hydration state, chain-end effect, poly (2-methoxyethyl acrylate), cyclic polymers, interfacial structures

\section{Introduction}

Water molecules existing at the interface between biomaterials and biological fluids play a crucial role in determining the fate of the components present in the fluids before and after adsorption on the surface of the material. Interactions between fluid components and surfaces occur hierarchically in the order of water, proteins, and cells. ${ }^{1}$ We previously studied the hydration state of biomaterials and observed that biocompatible synthetic polymers form three types of water: non-freezing water (NFW), intermediate water (IW), and free water (FW). ${ }^{2}$ It is well known that biomacromolecules such as protein, DNA, and RNA also contain IW. In contrast, non-biocompatible synthetic polymers do not enable IW formation. IW plays a key

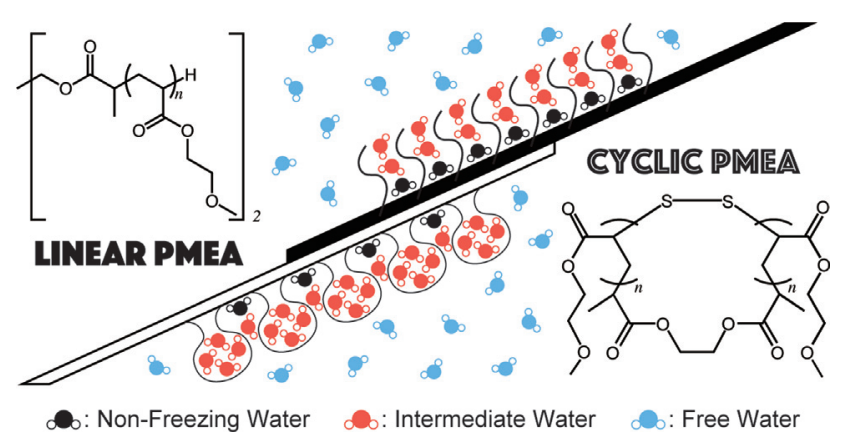

role in the biocompatibility of polymers and can influence protein adsorption and cell adhesion. ${ }^{2 f}$ Thus, molecular design that allows for the formation of IW offers significant advantages to those interested in synthetic biomaterials.

Water-insoluble polymers typically exhibit poor biocompatibility, as their hydrophobic characteristics often induce protein adsorption and denaturation. However, poly(2-methoxyethyl acrylate) (PMEA) ${ }^{2 \mathrm{e}}$ is an exception to this general rule. PMEA is a biocompatible synthetic polymer with superior surface antithrombogenicity, despite the fact that it is insoluble in water. The biocompatibility of PMEA is attributed to the methoxyethyl side chain, which ensures a balance between hydrophilicity and hydrophobicity, leading to the formation of $\mathrm{IW}^{2 \mathrm{f}}$ Owing to the attractive features of IW combined with water insolubility, PMEA has been used as an antithrombotic treatment material in biomedical devices. ${ }^{3}$ We have previously investigated various polymeric materials inspired by the chemical structure of PMEA to elucidate a suitable structure for controlling the formation and content of IW. ${ }^{4}$ However, the structure still needs to be optimized. For this purpose, we have focused on cyclic structures in this study. The biological response of a cyclic polymer is dissimilar to that of a linear polymer. This difference is rooted in the disparities between the polymer chain mobilities due to the loss of the chain end. ${ }^{5}$ As mentioned earlier, the hydration states, especially IW, directly affect the biological response of biomaterials. However, to date, there have been no reports on the relationship between the chain-end effect and IW formation. In this study, we synthesized a cyclic PMEA and described the chain-end effect on IW formation by comparative studies with a linear PMEA. The hydration-state analyses were performed by differential scanning calorimetry (DSC) and atomic force microscopy (AFM). 


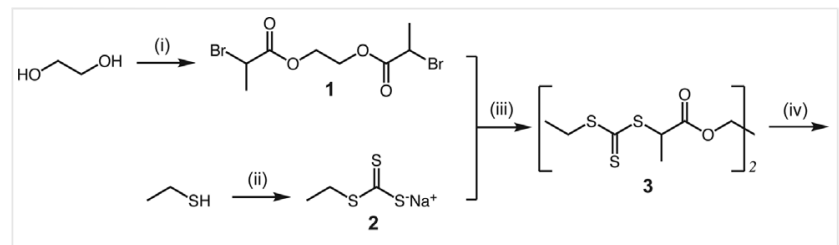

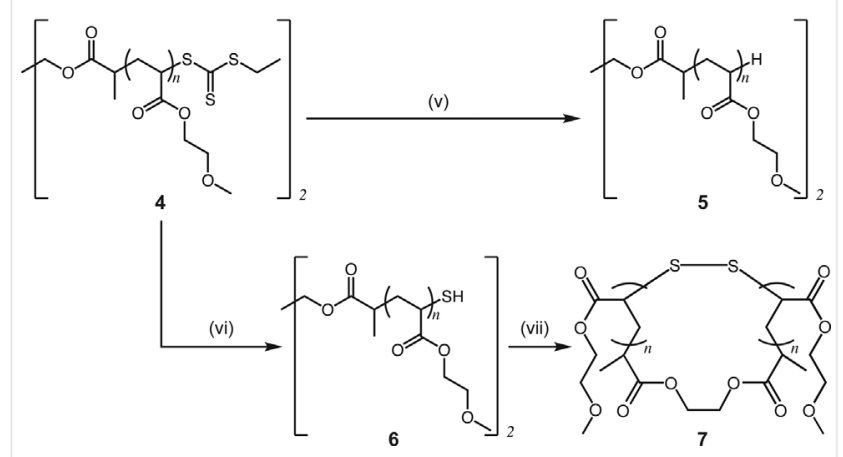

Scheme 1 Synthetic route to the linear and cyclic PMEA. (i) 2-Bromo-2methylpropanoyl bromide, pyridine, in THF, RT, 12 h. (ii) 1) sodium hydride, in diethyl ether, $0^{\circ} \mathrm{C}, 30 \mathrm{~min} ; 2$ ) carbon disulfide, in diethyl ether, RT, 2 h. (iii) In acetonitrile, RT, 24 h. (iv) MEA, AIBN, in toluene, 70 ${ }^{\circ} \mathrm{C}, 1 \mathrm{~h}$. (v) TTMSS, $\mathrm{V}-70$, in toluene, $40{ }^{\circ} \mathrm{C}, 12 \mathrm{~h}$. (vi) isobutylamine, in THF, RT, 2 h. (vii) iron(III) chloride, in diethyl ether/THF (v/v) =3/1, RT, 1 month.

\section{Results and Discussion}

We synthesized the linear PMEA (5) and cyclic PMEA (7) according to the pathway outlined in Scheme 1. Initially, the symmetrical bromopropanoate derivative 1 was synthesized by the condensation reaction of ethylene glycol and 2-bromopropanoyl bromide. ${ }^{6}$ The sodium salt of ethyl trithiocarbonate 2 was prepared by the addition of sodium ethanethiolate and carbon disulfide. ${ }^{7}$ The mono-bifunctional chain transfer agent, 3, was obtained via the $\mathrm{S}_{\mathrm{N}} 2$ reaction between 1 and $2{ }^{8}$ The obtained compounds 1-3 were characterized using ${ }^{1} \mathrm{H}$ and ${ }^{13} \mathrm{C}$ NMR spectroscopies (Figures $\mathrm{S} 1-\mathrm{S} 3$ ). We conducted the reversible addition-fragmentation chain transfer (RAFT) polymerization of 2-methoxyethyl acrylate (MEA) with 3 and isolated the polymer, a yellowcolored viscous liquid, by reprecipitation. ${ }^{9}$ The chemical structure of the product was determined by ${ }^{1} \mathrm{H}$ NMR spectroscopy. The number-average molecular weight $\left(M_{\mathrm{n}, \mathrm{NMR}}, M_{\mathrm{n}, \mathrm{SEC}}\right)$ and polydispersity index $(\nexists)$ were evaluated by ${ }^{1} \mathrm{H}$ NMR and size-exclusion chromatography (SEC) analyses, respectively. The SEC chromatograph was symmetrically unimodal and shifted toward a high molecular weight as the polymerization process proceeded (Figure 1, gray and black lines). The experimental value of $M_{\mathrm{n}, \mathrm{SEC}}$ agreed with the calculated theoretical value based on the monomer conversion $\left(M_{\mathrm{n}, \mathrm{SEC}}=76,300 \mathrm{~g} \mathrm{~mol}^{-1}, M_{\mathrm{n}, \text { theor }}=75,100 \mathrm{~g} \mathrm{~mol}^{-1}\right)$, and the dispersity was remarkably narrow $(\nexists=1.06)$. The presence of MEA units adjacent to the trithiocarbonate

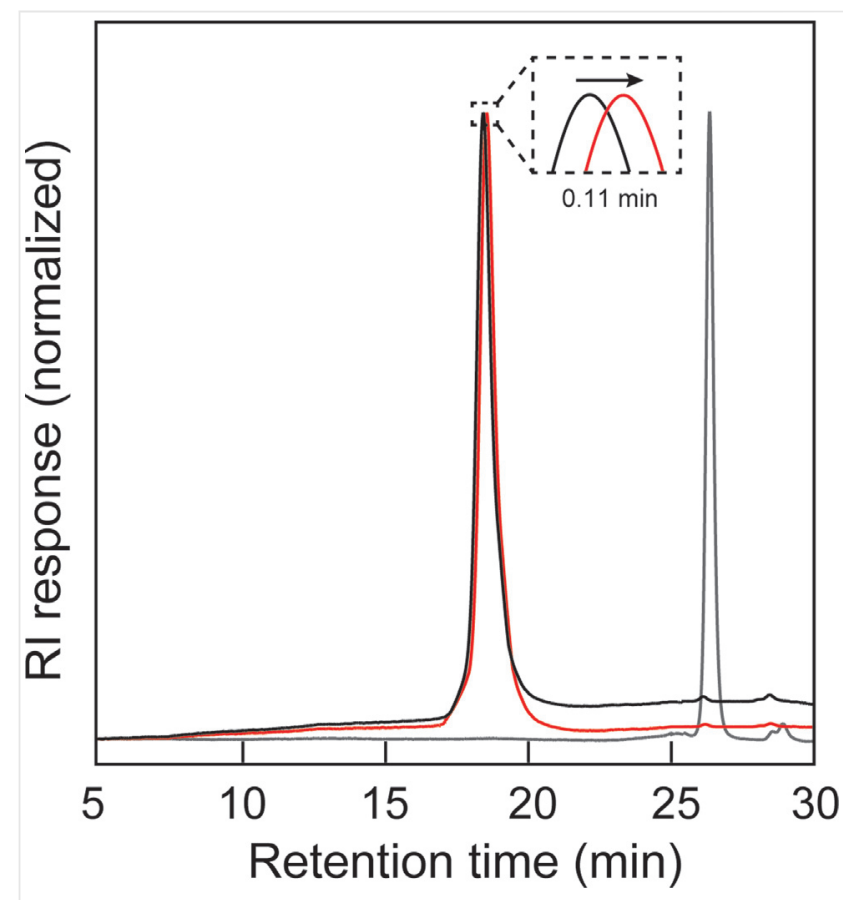

Figure 1 SEC chromatograms of acyclic telechelic PMEA before (4, black) and after (5, red) desulfurization and $\mathbf{3}$ (gray).

moieties was confirmed by the characteristic ${ }^{1} \mathrm{H}$ signal at ca. $4.7 \mathrm{ppm}$ (Figure S4, black line). By end-group analysis based on this signal, the $M_{\mathrm{n}, \mathrm{NMR}}$ was estimated to be $78,200 \mathrm{~g} \mathrm{~mol}^{-1}$, which also corresponded with the $M_{\mathrm{n}, \text { theor }}$ and $M_{\mathrm{n}, \mathrm{SEC}}$ values. From these results, we concluded that the RAFT polymerization of MEA proceeded successfully to give well-defined acyclic telechelic PMEA, 4. An end group, especially a hydrophobic and bulky group, often significantly affects the physical properties and morphology of polymers. ${ }^{10}$ Consequently, $\mathbf{4}$ is not suitable as a standard linear PMEA for evaluating the hydration state. Thus, desulfurization of $\mathbf{4}$ was performed by radical-induced reduction, ${ }^{11}$ and the resultant polymer was purified by reprecipitation to give the pure desulfurized-polymer $\mathbf{5}$, as a colorless viscous liquid. ${ }^{12}$ The SEC trace of $\mathbf{5}$ shifted slightly toward a low molecular weight while maintaining a narrow shape $\left(M_{\mathrm{n}, \mathrm{SEC}}=75,900 \mathrm{~g} \mathrm{~mol}^{-1}, Ð=1.09\right)$ (Figure 1, red line). In addition, the ${ }^{1} \mathrm{H}$ NMR peak corresponding to the methine moiety in the MEA units adjoining the trithiocarbonate groups was found to disappear (Figure S4, red line). This observation implies the successful progression of the reduction and translation of the end groups into hydrocarbons. The following experiments used $\mathbf{5}$ as the linear PMEA. Next, we attempted to prepare $\mathbf{7}$ via intramolecular cyclization of $6{ }^{13}$ In general, RAFT-synthesized polymers contain a thiocarbonylthio moiety at the end of the polymer chain that can be translated to a thiol group by treatment with nucleophiles 
and ionic reducing agents ${ }^{11 \mathrm{~b}}$ such as amines, ${ }^{14 \mathrm{a}}$ hydroxide, ${ }^{14 \mathrm{~b}}$ and borohydride. ${ }^{14 \mathrm{c}}$

In the presence of an oxidant, the thiol group spontaneously forms a disulfide bond, and this reaction is often employed to prepare cyclic structures. ${ }^{15}$ End-group conversion of 4 was carried out by treating with isobutylamine to give the desired thiol-terminated PMEA 6, as a colorless viscous liquid. Subsequently, $\mathbf{6}$ was dissolved in a large amount of diethyl ether/THF $(v / v=3 / 1)$ solution and treated with the strong oxidizing agent iron(III) chloride under high-dilution conditions to allow formation of a disulfide bond. ${ }^{15 a}$ SEC analyses were then performed on $\mathbf{6}$ at various time intervals using the same polymer concentrations (Figure 2). With an increase in the reaction time, the peak of the initial linear polymer between 18.5 and 20.7 min decreased, and a new peak appeared in a region of lower molecular weight (19.8-21.3 $\mathrm{min})$. This result suggests that the intramolecular cyclization reaction proceeds via disulfide formation because the SEC trace typically shifts to a higher molecular weight when intermolecular disulfide bonds are formed. Most importantly, the peak-top molecular weights of the starting material $\left(M_{\mathrm{p}, \mathrm{L}}\right)$ and the newly generated component $\left(M_{\mathrm{p}, \mathrm{C}}\right)$ were $88,200 \mathrm{~g} \mathrm{~mol}^{-1}$ and $63,500 \mathrm{~g} \mathrm{~mol}^{-1}$, respectively. The ratio of these molecular weights $\left(M_{\mathrm{p}, \mathrm{c}} / M_{\mathrm{p}, \mathrm{L}}\right)$, which is an index that indicates the generation of cyclic polymers, was calculated to be 0.72 . The value is consistent with those in previous reports. ${ }^{16}$ The resultant polymer was isolated, and a part of it was reduced using a zinc/acetic acid system and analyzed by

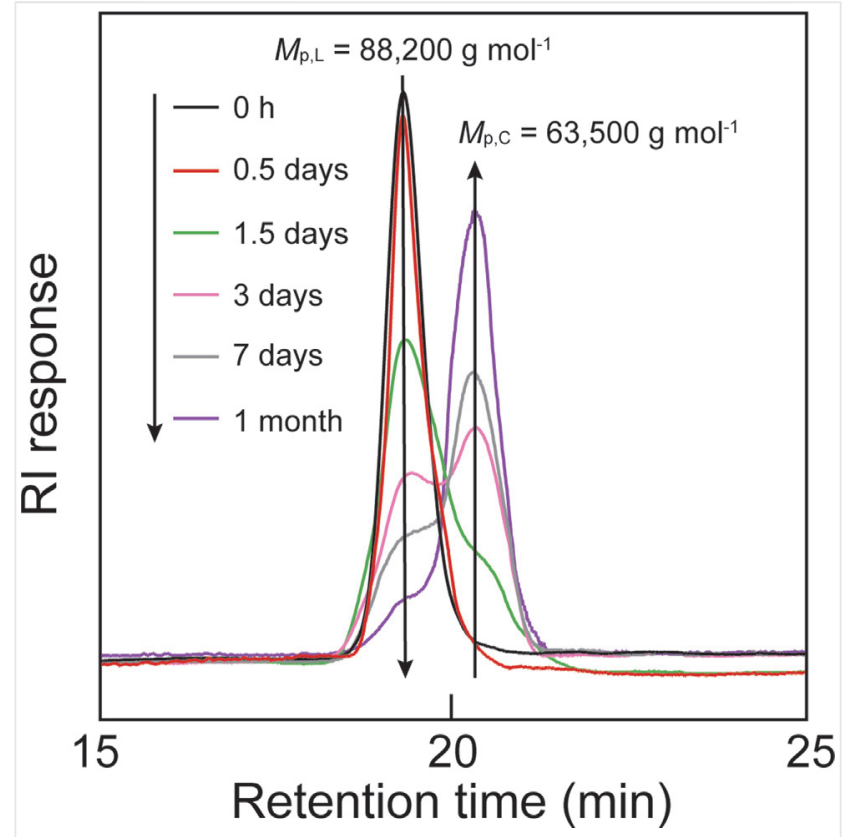

Figure 2 SEC chromatogram changes of thiol terminated-telechelic PMEA, $\mathbf{6}$, with along through progress of oxidization using iron(III) chloride.
SEC measurement (Figure S5). The peak of 7 clearly shifted toward a higher molecular weight and almost matched that of the initial linear polymer, suggesting that the resultant polymer has a cyclic structure. The chemical structure of the resultant polymer was determined by ${ }^{1} \mathrm{H}$ NMR spectroscopy and assigned to the PMEA backbone (Figure S6). In addition, the glass transition temperature $\left(T_{\mathrm{g}}\right)$ of the polymer after oxidization was estimated to be $-36.5^{\circ} \mathrm{C}$ from the DSC thermogram, which differed appreciably from the transition temperature of $\mathbf{5}\left(-38.8^{\circ} \mathrm{C}\right)$ (Figure S7). It is well known that cyclic polymers show higher $T_{\mathrm{g}}$ values than linear polymers. ${ }^{17}$ Thus, we concluded that the obtained polymer, 7 , consists mostly of a cyclic structure ( $>80 \%$ ) and can be used to evaluate the impact of the chain-end effect on hydration states. 7 was used in subsequent experiments as the cyclic PMEA.

The precise amounts of hydration water (NFW, IW, and FW) in the hydrated polymers were easily determined by DSC measurements. ${ }^{2 \mathrm{f}}$ Polymers $\mathbf{5}$ and $\mathbf{7}$ were saturated in pure water and evaluated based on DSC measurements (Figure S8). For both polymers, the cold crystallization temperature of the water, derived from IW, was confirmed to be approximately $-40{ }^{\circ} \mathrm{C}$. The $T_{\mathrm{g}, \mathrm{dry}}$ of 7 , without the chain end, was higher than that of $\mathbf{5}$ owing to the decreased mobility of the polymer chain. In contrast, the $T_{\mathrm{g} \text {,water }}$ of $\mathbf{7}$ $\left(-50.8^{\circ} \mathrm{C}\right)$ was lower than that of $5\left(-48.4^{\circ} \mathrm{C}\right)$. In general, $T_{\mathrm{g}}$ decreases when the water content is high, even for the same polymer species. ${ }^{18}$ These results suggest that the amount of diffused water in $\mathbf{7}$ is larger than that in $\mathbf{5}$. The content and quantity of the three types of water per unit weight of the polymer were calculated from the enthalpy variation of water and the weight difference between the dry and wet polymers (Figure 3a). The water contents of hydrated $\mathbf{5}$ and 7 were estimated to be $9.4 \%$ and $12.2 \%$, respectively. Thus, polymer $\mathbf{7}$, without the chain end, took up more water because the free volume of the cyclic polymer was smaller than that of the linear polymer. In fact, it has been reported that cyclic polymers can contain significantly more water
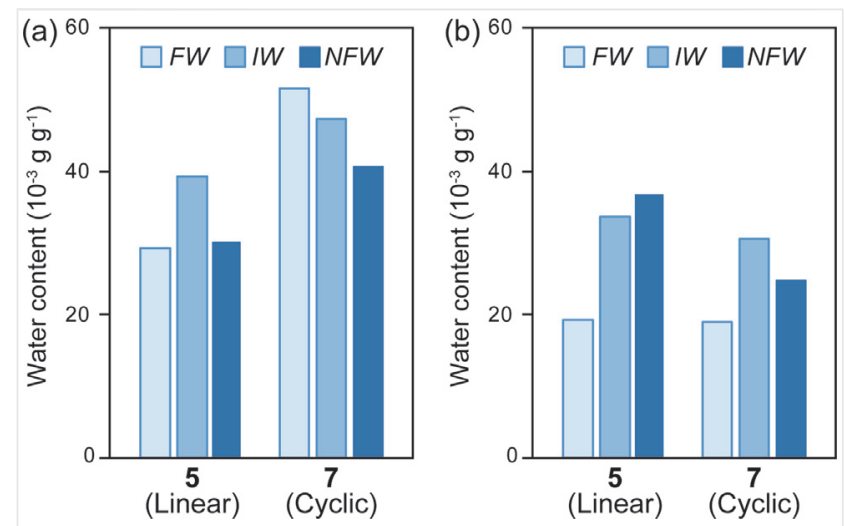

Figure 3 Summary of hydration state analyses for $\mathbf{5}$ and $\mathbf{7}$ in pure water (a) and PBS (b) systems. 
than linear polymers as they experience less entanglement. ${ }^{19}$ Importantly, the increased water content in $\mathbf{7}$ is mostly composed of FW and IW (76\%). It is known that water confined in a nano space exhibits freezing behavior similar to FW and IW depending on the space size. ${ }^{20}$ The diameter of the nano space in the cyclic polymer $\mathbf{7}$ in pure water $\left(2\left\langle R_{\mathrm{g}, \mathrm{c}}\right\rangle\right)$ is estimated to be about $2.1 \mathrm{~nm}$ from the following equation ${ }^{21}$ :

$$
\left\langle R_{\mathrm{g}, \mathrm{c}}{ }^{2}\right\rangle=\frac{n b^{2}}{12}
$$

where $n$ is the number of segments (polymerization degree), and $b$ is the length of each segment. The obtained value is optimum for water to form clusters, that is, cold crystallization. ${ }^{20 a}$ We concluded that a molecular structure without a chain end like that in $\mathbf{7}$ can provide an appropriate-sized nano space to promote the diffusion of water molecules and the formation of FW and IW. Thus, we clarified that the chain end of the polymer affected the hydration state; thus, the formation of IW in pure water was nourished by cyclization. Subsequently, the hydration states of the polymers were examined in phosphate-buffered saline (PBS) using DSC measurements (Figure S9). These experiments are essential to identify hydrated water that is crucial for biocompatibility because biological responses usually occur under physiological ionic conditions. Figure $3 \mathrm{~b}$ shows the quantified hydrated water in the polymers. Although the $T_{\mathrm{g}, \mathrm{PBS}}$ values of these polymers were almost the same, the water content of hydrated 7 (6.9\%) was lower than that of 5 (8.2\%). In addition, the amounts of FW and IW in $\mathbf{7}$ were slightly lower than those in polymer $\mathbf{5}$.

These results indicated that the formation of FW and IW due to confinement in the nano space of 7 was partially expelled by the osmotic effect and shrinkage of the polymer matrix, ${ }^{4 \mathrm{~d}}$ suggesting that the chain length of 7 was too long to maintain the IW. This is because the nano spaces formed in a large cyclic polymer, wherein the main chain is relatively flexible compared to that of a small cyclic polymer, easily collapse. This osmotic pressure induced the shrinkage of $\mathbf{7}$ compared with $\mathbf{5}$ because the cyclic polymer has low mobility and easily interacts between the MEA units in a molecule. Therefore, water molecules are interrupted to approach the MEA units, resulting that the NFW content formed on 7 in PBS was drastically declined compared with $\mathbf{5}$. Thus, it would be possible to control IW formation by adjusting the length of the polymer chains and optimizing the size of the nano space.

Interactions between polymers and biomolecules occur at the interfaces. Therefore, it is important to understand not only the fundamental physical properties of the polymer and the hydrated state obtained by DSC, but also the hydration state of the polymer surface. We prepared surfaces of 5 and 7 by spin-coating and measured water and air contact angles to investigate the hydration state. The water contact angles immediately after the aqueous contact were estimated to be $82.4^{\circ} \pm 0.5^{\circ}$ and $90.1^{\circ} \pm 0.5^{\circ}$, respectively. After $30 \mathrm{~s}$, the water contact angle of 5 decreased to $40.0^{\circ} \pm 0.1^{\circ}$ via the polymer chain orientation. In contrast, the water contact angle of $\mathbf{7}$ did not change significantly $\left(83.5^{\circ} \pm 0.2^{\circ}\right)$ (Figure S10). These observations reflect that the chain orientation in polymer 7 occurred slowly because the mobility of $\mathbf{7}$ was lower than that of $\mathbf{5}$. The air contact angle was measured after immersion in PBS. The air contact angles of $\mathbf{5}$ and $\mathbf{7}$ are almost the same $\left(147.8^{\circ} \pm 0.9^{\circ}\right.$ and $147.3^{\circ} \pm 1.4^{\circ}$, respectively), indicating that the water contents of $\mathbf{5}$ and $\mathbf{7}$ are almost the same at the polymer/PBS interface. The hydration state at the interface was analyzed using AFM in greater detail. AFM is an efficient method for deciphering the hydration state at the polymer/water interface. Recently, we reported that the structure at the polymer/water interface differs depending on the presence of IW. ${ }^{22 a}$ It was previously reported that a linear PMEA exhibited a heterogeneous interfacial structure at the polymer/PBS interface based on the phase separation of polymer-rich and water-rich domains. ${ }^{22 b}$ Furthermore, protein adsorption was suppressed in water-rich domains where a large amount of IW existed. ${ }^{22 c}$ In this study, a similar structure was also observed at the 7/PBS interface (Figure 4). The bright area is polymer-rich domains and the dark area is water-rich domains. Because tiny polymer density in the water-rich domains is not detectable by AFM, polymer-rich domains are observed as nanometer-scale protrusions at the interface. Figure 4 suggests that the surface of $\mathbf{7}$ was filled with IW. We perceive that the polymer-rich domains (island parts) are larger and the area covered by water-rich domains is smaller for $\mathbf{7}$ than for $\mathbf{5}$. The estimated area percentages of the water-rich domains that have been averaged from the image analysis of five 5 $\mu \mathrm{m} \times 5 \mu \mathrm{m}$ images were $84.8 \pm 0.7 \%$ for $\mathbf{5}$ and $79.5 \pm 1.0 \%$ for 7. The reason for the formation of larger polymer-rich domains in $\mathbf{7}$ compared to $\mathbf{5}$ is that the cyclic chains facilitated phase separation at the polymer/water interface. It is expected that the water-rich domain includes a larger amount of IW than the polymer-rich domain in previous studies. $^{22 \text { bd }}$ Thus, we concluded that 7 retains a smaller
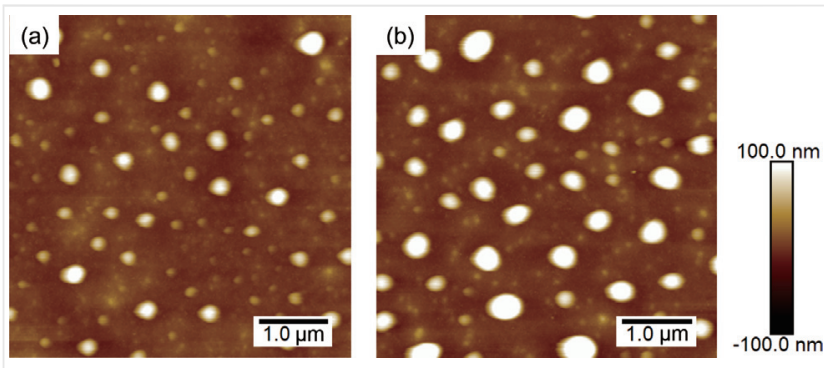

Figure 4 AFM images of (a) 5 and (b) 7 in PBS. 
amount of IW than $\mathbf{5}$ at the interface as well as in the bulk state, as depicted by the DSC measurements (Figure $3 \mathrm{~b}$ ). The difference between $\mathbf{5}$ and $\mathbf{7}$ is more significant than that in Figure $3 \mathrm{~b}$ because the water content of PMEA in the interface is much higher than that in the bulk state. ${ }^{23}$ Platelets sufficiently suppressed the adhesion and activation on the surfaces of both polymers as compared to the bare polyethylene terephthalate surfaces (Figure S11). Previously, we had reported that the platelet adhesion on the PMEA brush samples was quite low when the area percentage of the water-rich domain was over $40 \%{ }^{22 \mathrm{~d}}$ These results indicated that a sufficient amount of IW was present at both interfaces to prevent platelet adhesion.

\section{Conclusions}

In this study, we synthesized well-defined linear and cyclic PMEAs and investigated the chain-end effect for IW formation using comparative experiments. DSC analysis indicated that the amount of IW in the linear and cyclic PMEAs showed a minor difference in the PBS system. In contrast, the cyclic structure provided nano spaces of moderate size and promoted the formation of IW in the pure water system. AFM observations indicated that the surface of the cyclic PMEA exhibited slightly different phase separation behavior from that of the linear PMEA. Hence, the chain-end effect certainly influenced the hydration state, including the IW. The insights obtained from this study suggest the possibility of controlling IW formation, and provide a promising opportunity for the design of biomaterials based on "the intermediate water concept".

\section{Funding Information}

This work was supported by Grants-in-Aid for Scientific Research (KAKENHI) (JP19H05720 to M. T. and JP20J00282 to S.N.) from the Japan Society for the Promotion of Science (JSPS) and "Dynamic Alliance Open Innovation Bridging Human, Environment and Materials" from the Ministry of Education, Culture, Sports, Science and Technology of Japan (MEXT).

\section{Supporting Information}

Supporting information for this article is available online at https://doi.org/10.1055/a-1441-8239.

\section{References And Notes}

(1) (a) Tsuruta, T. J. Biomater. Sci., Polym. Ed. 2010, 21, 1831. (b) Brash, J. L.; Horbett, T. A.; Latour, R. A.; Tengvall, P. Acta Biomater. 2019, 94, 11.
(2) (a) Tanaka, M.; Motomura, T.; Ishii, N.; Shimura, K.; Onishi, M.; Mochizuki, A.; Hatakeyama, T. Polym. Int. 2000, 49, 1709. (b) Tanaka, M.; Motomura, T.; Kawada, M.; Anzai, T.; Kasori, Y.; Shiroya, T.; Shimura, K.; Onishi, M.; Mochizuki, A. Biomaterials 2000, 21, 1471. (c) Fujita, K.; Nikawa, Y.; Ohno, H. Chem. Commun. 2013, 49, 3257. (d) Nikawa, Y.; Tsuzuki, S.; Ohno, H.; Fujita, K. Aust. J. Chem. 2019, 72, 392. (e) Okada, M.; Hara, E.; Kobayashi, D.; Kai, S.; Ogura, K.; Tanaka, M.; Matsumoto, T. ACS Appl. Bio Mater. 2019, 2, 981. (f) Tanaka, M.; Kobayashi, S.; Murakami, D.; Aratsu, F.; Kashiwazaki, A.; Hoshiba, T.; Fukushima, K. Bull. Chem. Soc. Jpn. 2019, 92, 2043.

(3) (a) Vang, S. N.; Brady, C. P.; Christensen, K. A.; Isler, J. R.; Allen, K. R. J. Extra Corpor. Technol. 2005, 37, 23. (b) Kariya, S.; Nakatani, M.; Ono, Y.; Maruyama, T.; Ueno, Y.; Komemushi, A.; Tanigawa, N. Cardiovasc. Interventional Radiol. 2020, 43, 775.

(4) (a) Sato, K.; Kobayashi, S.; Kusakari, M.; Watahiki, S.; Oikawa, M.; Hoshiba, T.; Tanaka, M. Macromol. Biosci. 2015, 15, 1296. (b) Kobayashi, S.; Wakui, M.; Iwata, Y.; Tanaka, M. Biomacromolecules 2017, 18, 3834. (c) Nishimura, S.; Ueda, T.; Kobayashi, S.; Tanaka, M. ACS Appl. Polym. Mater. 2020,2, 4790.(d) Sonoda, T.; Kobayashi, S.; Herai, K.; Tanaka, M. Macromolecules 2020, 53, 8570.

(5) (a) Damodaran, V. B.; Murthy, N. S. Biomater. Res. 2016, 20, 18. (b) Wei, T.; Zhou, Y.; Zhan, W.; Zhang, Z.; Zhu, X.; Yu, Q.; Chen, H. Colloids Surf., B 2017, 159, 527. (c) Trachsel, L.; Romio, M.; Grob, B.; Zenobi-Wong, M. ACS Nano 2020, 14, 10054. (d) Shin, E.; Lim, C.; Kang, U. J.; Kim, M.; Park, J.; Kim, D.; Choi, W.; Hong, J.; Lee, D. W.; Kim, B. S. Macromolecules 2020, 53, 3551.

(6) Synthetic procedure for compound 1: Ethylene glycol (dehydrated) $2.48 \mathrm{~g}$ ( $40 \mathrm{mmol}$ ) and pyridine $7.26 \mathrm{~mL}$ (90 mmol) were dissolved in dry THF $60 \mathrm{~mL}$ and cooled to $0{ }^{\circ} \mathrm{C}$. Then, 2bromopropanoyl bromide $9.43 \mathrm{~mL}$ (90 mmol) was diluted with dry THF $10 \mathrm{~mL}$ and added dropwise to the mixture and reacted at RT for $15 \mathrm{~h}$. The resultant mixture was concentrated in vacuo and $100 \mathrm{~mL}$ of hexane/ethyl acetate $(\mathrm{v} / \mathrm{v}=1 / 1)$ mixture solution was added. The solution was washed with sat. sodium hydrogen carbonate aqueous solution $100 \mathrm{~mL} \times 5,1 \mathrm{M}$ sodium hydrogen sulfate aqueous solution $100 \mathrm{~mL} \times 3$, and water $100 \mathrm{~mL} \times 3$. An organic layer was collected and dried over magnesium sulfate anhydrous. The solvents were removed in vacuo to give an objective ethane-1,2-diyl bis(2-bromopropanoate), 1, as a colorless oil (10.12 g, 76.2\%). ${ }^{1}$ H NMR [400 MHz, $\mathrm{CDCl}_{3}$, tetramethylsilane (TMS)] (Figure S1a): $\sigma=1.85 \mathrm{ppm}((-$ $\left.\left.\mathrm{CH}_{2} \mathrm{OC}(=\mathrm{O}) \mathrm{CH}\left(\mathrm{CH}_{3}\right) \mathrm{Br}\right)_{2} d, 6 \mathrm{H}\right), 4.40 \mathrm{ppm}\left(\left(-\mathrm{CH}_{2} \mathrm{OC}(=\mathrm{O}) \mathrm{CH}\left(\mathrm{CH}_{3}\right)\right.\right.$ $\left.\mathrm{Br})_{2} q, 2 \mathrm{H}\right), 4.43 \mathrm{ppm}\left(\left(-\mathrm{CH}_{2} \mathrm{OC}(=\mathrm{O}) \mathrm{CH}\left(\mathrm{CH}_{3}\right) \mathrm{Br}\right)_{2} \mathrm{~S}, 4 \mathrm{H}\right) .{ }^{13} \mathrm{C}$ NMR [75 MHz, $\mathrm{CDCl}_{3}$, TMS] (Figure S1b): $\sigma=21.6 \mathrm{ppm}((-$ $\left.\left.\mathrm{CH}_{2} \mathrm{OC}(=\mathrm{O}) \mathrm{CH}\left(\mathrm{CH}_{3}\right) \mathrm{Br}\right)_{2}\right), \quad 39.6 \mathrm{ppm} \quad\left(\left(-\mathrm{CH}_{2} \mathrm{OC}(=\mathrm{O}) \mathrm{CH}\left(\mathrm{CH}_{3}\right)\right.\right.$ $\left.\mathrm{Br})_{2}\right), 63.3 \mathrm{ppm}\left(\left(-\mathrm{CH}_{2} \mathrm{OC}(=\mathrm{O}) \mathrm{CH}\left(\mathrm{CH}_{3}\right) \mathrm{Br}\right)_{2}\right), 170.1 \mathrm{ppm} \quad((-$ $\left.\mathrm{CH}_{2} \mathrm{OC}(=\mathrm{O}) \mathrm{CH}\left(\mathrm{CH}_{3}\right) \mathrm{Br}\right)_{2}$.

(7) Synthetic procedure for compound 2: Sodium hydride $6.68 \mathrm{~g}$ $(0.167 \mathrm{~mol})$ was dispersed to dry diethyl ether $200 \mathrm{~mL}$ and cooled to $0{ }^{\circ} \mathrm{C}$ under an argon gas atmosphere. Ethanethiol $13.3 \mathrm{~mL}(0.185 \mathrm{~mol})$ was added dropwise to the dispersion solution and its mixture was stirred for $15 \mathrm{~min}$. Then, carbon disulfide $11.2 \mathrm{~mL}(0.185 \mathrm{~mol})$ was added and reacted at RT for $1 \mathrm{~h}$. After reaction, the reaction mixture was added $n$-pentane $100 \mathrm{~mL}$ to precipitate a resultant sodium salt of trithiocarbonate. The precipitation was collected by filtration and washed with $n$-pentane $400 \mathrm{~mL}$ to give an objective sodium ethyl carbonotrithioate, 2 , as a yellow powder (25.0 g, 93.4\%). ${ }^{1} \mathrm{H}$ NMR [400 MHz, DMSO- $d_{6}$, TMS] (Figure S2a): $\sigma=1.14 \mathrm{ppm}$ $\left(\mathrm{CH}_{3} \mathrm{CH}_{2} \mathrm{SC}(=\mathrm{S}) \mathrm{SNa}, t, 3 \mathrm{H}\right), 2.96 \mathrm{ppm}\left(\mathrm{CH}_{3} \mathrm{CH}_{2} \mathrm{SC}(=\mathrm{S}) \mathrm{SNa}, q, 2\right.$ H). ${ }^{13} \mathrm{C}$ NMR [100 MHz, DMSO- $d_{6}$, TMS] (Figure S2b): $\sigma=14.6$ 
ppm $\quad\left(\mathrm{CH}_{3} \mathrm{CH}_{2} \mathrm{SC}(=\mathrm{S}) \mathrm{SNa}\right), \quad 34.3 \mathrm{ppm} \quad\left(\mathrm{CH}_{3} \mathrm{CH}_{2} \mathrm{SC}(=\mathrm{S}) \mathrm{SNa}\right)$, $240.1 \mathrm{ppm}\left(\mathrm{CH}_{3} \mathrm{CH}_{2} \mathrm{SC}(=\mathrm{S}) \mathrm{SNa}\right)$.

(8) Synthetic procedure for compound 3: $7.6 \mathrm{~g}$ of $\mathbf{1}$ (47.4 mmol) and freshly prepared $3.2 \mathrm{~g}$ of $\mathbf{2}(9.5 \mathrm{mmol})$ were dissolved to acetonitrile $30 \mathrm{~mL}$ and stirred at RT for 1.5 days. The reaction mixture was added diethyl ether $200 \mathrm{~mL}$ and washed with water $200 \mathrm{~mL} \times 4$. An organic layer was collected and dried over magnesium sulfate anhydrous. The solution was concentrated to give an objective ethane-1,2-diyl bis(2-(((ethylthio)carbonothioyl)thio)propanoate, 3, as an orange oil (3.6 g, 92.1\%). ${ }^{1} \mathrm{H}$ NMR [400 MHz, $\mathrm{CDCl}_{3}$, TMS] (Figure S3a): $\sigma=1.26 \mathrm{ppm}((-$ $\left.\mathrm{CH}_{2} \mathrm{OC}(=\mathrm{O}) \mathrm{CH}\left(\mathrm{CH}_{3}\right) \mathrm{SC}(=\mathrm{S}) \mathrm{S}-\mathrm{CH}_{2} \mathrm{CH}_{32} t, 6 \mathrm{H}\right), 1.54 \mathrm{ppm}\left(\left(-\mathrm{CH}_{2} \mathrm{OC}\right.\right.$ $\left.(=\mathrm{O}) \mathrm{CH}\left(\mathrm{CH}_{3}\right) \mathrm{SC}(=\mathrm{S}) \mathrm{SCH}_{2} \mathrm{CH}_{32} t, 6 \mathrm{H}\right), 3.29 \mathrm{ppm}\left(\left(-\mathrm{CH}_{2} \mathrm{OC}(=\mathrm{O}) \mathrm{CH}\right.\right.$ $\left.\left(\mathrm{CH}_{3}\right) \mathrm{SC}(=\mathrm{S}) \mathrm{SCH}_{2} \mathrm{CH}_{32} q, 4 \mathrm{H}\right), 4.28 \mathrm{ppm}\left(\left(-\mathrm{CH}_{2} \mathrm{OC}(=\mathrm{O}) \mathrm{CH}\left(\mathrm{CH}_{3}\right) \mathrm{SC}\right.\right.$ $\left.(=\mathrm{S}) \mathrm{S}-\mathrm{CH}_{2} \mathrm{CH}_{32} \mathrm{~S}, 4 \mathrm{H}\right), 4.77 \mathrm{ppm}\left(\left(-\mathrm{CH}_{2} \mathrm{OC}(=\mathrm{O}) \mathrm{CH}\left(\mathrm{CH}_{3}\right) \mathrm{SC}(=\mathrm{S})\right.\right.$ $\mathrm{SCH}_{2} \mathrm{CH}_{32} q, 2 \mathrm{H}$ ). ${ }^{13} \mathrm{C}$ NMR [100 $\mathrm{MHz}, \mathrm{CDCl}_{3}$, TMS] (Figure S3b): $\sigma=12.7 \mathrm{ppm} \quad\left(\left(-\mathrm{CH}_{2} \mathrm{OC}(=\mathrm{O}) \mathrm{CH}\left(\mathrm{CH}_{3}\right) \mathrm{SC}(=\mathrm{S}) \mathrm{S}-\mathrm{CH}_{2} \mathrm{CH}_{32}\right)\right.$, $16.8 \mathrm{ppm}\left(\left(-\mathrm{CH}_{2} \mathrm{OC}(=\mathrm{O}) \mathrm{CH}\left(\mathrm{CH}_{3}\right) \mathrm{SC}(=\mathrm{S}) \mathrm{SCH}_{2} \mathrm{CH}_{32}\right), \quad 31.6 \mathrm{ppm}\right.$ $\left(\left(-\mathrm{CH}_{2} \mathrm{OC}(=\mathrm{O}) \mathrm{CH}-\left(\mathrm{CH}_{3}\right) \mathrm{SC}(=\mathrm{S}) \mathrm{SCH}_{2} \mathrm{CH}_{32}\right), 47.9 \mathrm{ppm}\left(\left(-\mathrm{CH}_{2} \mathrm{OC}\right.\right.\right.$ $\left.(=\mathrm{O}) \mathrm{CH}\left(\mathrm{CH}_{3}\right) \mathrm{SC}(=\mathrm{S}) \mathrm{SCH}_{2} \mathrm{CH}_{32}\right), \quad 63.1 \mathrm{ppm} \quad\left(\left(-\mathrm{CH}_{2} \mathrm{OC}(=\mathrm{O}) \mathrm{CH}\right.\right.$ $\left.\left(\mathrm{CH}_{3}\right) \mathrm{SC}(=\mathrm{S}) \mathrm{SCH}_{2} \mathrm{CH}_{32}\right), \quad 170.9 \mathrm{ppm} \quad\left(\left(-\mathrm{CH}_{2} \mathrm{OC}(=\mathrm{O}) \mathrm{CH}\left(\mathrm{CH}_{3}\right) \mathrm{SC}\right.\right.$ $\left.(=\mathrm{S}) \mathrm{SCH}_{2}-\mathrm{CH}_{32}\right), \quad 221.9 \mathrm{ppm} \quad\left(\left(-\mathrm{CH}_{2} \mathrm{OC}(=\mathrm{O}) \mathrm{CH}\left(\mathrm{CH}_{3}\right) \mathrm{SC}(=\mathrm{S})\right.\right.$ $\mathrm{SCH}_{2} \mathrm{CH}_{32}$.

(9) Synthetic procedure for compound 4: MEA $5.00 \mathrm{~g}$ $(38.40 \mathrm{mmol}), 317.15 \mathrm{mg}(3.48 \mu \mathrm{mol})$, and AIBN $5.50 \mathrm{mg}$ ( $3.48 \mu \mathrm{mol}$ ) were dissolved to toluene (monomer concentration: $4 \mathrm{M}$ ), and the solution was degassed over freeze-pump-thaw cycles (three times) under an argon gas atmosphere. Then the reaction mixture was placed in a preheated oil bath at $60{ }^{\circ} \mathrm{C}$. After polymerization for $1 \mathrm{~h}$, the mixture was cooled to RT and poured into a large excess of hexane to precipitate the resulting polymer. The polymer was further purified by a reprecipitation method from the THF/hexane system. The solvents were removed in vacuo to give a pure telechelic PMEA, 4, as a yellow-colored viscosity liquid (Conv.: 77.6\%). ${ }^{1} \mathrm{H}$ NMR [400 MHz, $\mathrm{CDCl}_{3}$, TMS] (Figure 1b, black): $\sigma=1.26-3.0 \mathrm{ppm}$ $\left(-\mathrm{SC}(=\mathrm{S}) \mathrm{SCH}_{2} \mathrm{CH}_{3} \mathrm{t}, 6 \mathrm{H}\right.$ (both end); $-\left(\mathrm{CH}_{3}\right) \mathrm{CH}(=\mathrm{O}) \mathrm{OCCH}_{2} \mathrm{CH}_{2} \mathrm{OC}$ $(=\mathrm{O}) \mathrm{CH}\left(\mathrm{CH}_{3}\right)-, t, 6 \mathrm{H}$; PMEA, methylene (main chain), $2(1-x n \mathrm{H}$; PMEA, methine (main chain), (1-xnH), 3.26-3.47 ppm $(-\mathrm{SC}(=\mathrm{S})$ $\mathrm{SCH}_{2} \mathrm{CH}_{3} q, 4 \mathrm{H}$ (both end); $-\mathrm{CO}(=\mathrm{O}) \mathrm{CH}_{2} \mathrm{CH}_{2} \mathrm{OCH}_{3}, 3(1-x n \mathrm{H})$, $3.48-3.70 \mathrm{ppm} \quad\left(-\mathrm{CO}(=\mathrm{O}) \mathrm{CH}_{2} \mathrm{CH}_{2} \mathrm{OCH}_{3}, \quad 2(1-x n \mathrm{H}), \quad 4.00-\right.$ $4.47 \mathrm{ppm}\left(-\left(\mathrm{CH}_{3}\right) \mathrm{CH}(=\mathrm{O}) \mathrm{OCCH}_{2} \mathrm{CH}_{2} \mathrm{OC}(=\mathrm{O}) \mathrm{CH}\left(\mathrm{CH}_{3}\right)-\right.$, s, $4 \mathrm{H}$; $\mathrm{CO}(=\mathrm{O}) \mathrm{CH}_{2} \mathrm{CH}_{2} \mathrm{O}-\mathrm{CH}_{3}, \quad 2(1-x n \mathrm{H}), \quad 4.77 \mathrm{ppm} \quad\left(-\left(\mathrm{CH}_{3}\right) \mathrm{CH}(=\mathrm{O})\right.$ $\left.\mathrm{OCCH}_{2} \mathrm{CH}_{2} \mathrm{OC}(=\mathrm{O}) \mathrm{CH}\left(\mathrm{CH}_{3}\right)-, q, 2 \mathrm{H}\right)$. SEC [THF, $40{ }^{\circ} \mathrm{C}$, PSt standard] (Figure 1a, black): $M_{\mathrm{n}, \mathrm{SEC}}=76,300 \mathrm{~g} \mathrm{~mol}^{-1}, \oplus M_{\mathrm{w}} /$ $\left.M_{\mathrm{n}}\right)=1.06$.

(10) Kujawa, P.; Segui, F.; Shaban, S.; Diab, C.; Okada, Y.; Tanaka, F.; Winnik, F. M. Macromolecules 2006, 39, 341.

(11) (a) Chong, Y. K.; Moad, G.; Rizzardo, E.; Thang, S. H. Macromolecules 2007, 40, 4446. (b) Willcock, H.; O’Reilly, R. K. Polym. Chem. 2010, 1, 149.

(12) Synthetic procedure for compound 5: $41.0 \mathrm{~g}(13.1 \mu \mathrm{mol})$, TTMSS $65.1 \mathrm{mg}(262.0 \mu \mathrm{mol})$, and V-70 $2.0 \mathrm{mg}(6.5 \mu \mathrm{mol})$ were dissolved to toluene $5 \mathrm{~mL}$. The colored solution was deoxygenated by freeze-pump-thaw cycles (three times). Then the reaction mixture was stirred at $40{ }^{\circ} \mathrm{C}$ for $12 \mathrm{~h}$, resulting in a colorless solution. The solution was poured into a large excess of hexane to precipitate an objective polymer. The polymer was further purified by a reprecipitation method from the $\mathrm{THF} /$ hexane system to give a pure desulfurized-PMEA, 5, as a colorless viscosity liquid $(0.88 \mathrm{~g}) .{ }^{1} \mathrm{H}$ NMR $\left[400 \mathrm{MHz}, \mathrm{CDCl}_{3}\right.$, TMS] (Figure 1b, red): $\sigma=1.30-3.0 \mathrm{ppm} \quad\left(-\left(\mathrm{CH}_{3}\right) \mathrm{CH}(=\mathrm{O})\right.$
$\mathrm{OCCH}_{2}-\mathrm{CH}_{2} \mathrm{OC}(=\mathrm{O}) \mathrm{CH}\left(\mathrm{CH}_{3}\right)-, t, 6 \mathrm{H}$; PMEA, methylene (main chain), 2(1-xnH; PMEA, methine (main chain), (1-xnH), 3.26$3.47 \mathrm{ppm}\left(-\mathrm{CO}(=\mathrm{O}) \mathrm{CH}_{2} \mathrm{CH}_{2} \mathrm{OCH}_{3}, 3(1-x n \mathrm{H}), 3.48-3.70 \mathrm{ppm}(-\right.$ $\mathrm{CO}(=\mathrm{O}) \mathrm{CH}_{2} \mathrm{CH}_{2} \mathrm{OCH}_{3}, 2(1-x n \mathrm{H}), 4.00-4.47 \mathrm{ppm}\left(-\left(\mathrm{CH}_{3}\right) \mathrm{CH}(=\mathrm{O})\right.$ $\mathrm{OCCH}_{2} \mathrm{CH}_{2} \mathrm{OC}(=\mathrm{O}) \mathrm{CH}-\left(\mathrm{CH}_{3}\right)-, \mathrm{s}, 4 \mathrm{H} ;-\mathrm{CO}(=\mathrm{O}) \mathrm{CH}_{2} \mathrm{CH}_{2} \mathrm{OCH}_{3}, 2$ $(1-x n \mathrm{H}), \quad 4.77 \mathrm{ppm} \quad\left(-\left(\mathrm{CH}_{3}\right) \mathrm{CH}(=\mathrm{O}) \mathrm{OCCH}_{2} \mathrm{CH}_{2} \mathrm{O}-\mathrm{C}(=\mathrm{O}) \mathrm{CH}\right.$ $\left.\left(\mathrm{CH}_{3}\right)-, q, 2 \mathrm{H}\right) . \mathrm{SEC}\left[\mathrm{THF}, 40^{\circ} \mathrm{C}\right.$, PSt standard] (Figure $1 \mathrm{a}$, red): $M_{\mathrm{n}}=75,900 \mathrm{~g} \mathrm{~mol}^{-1}, Ð=1.09$.

(13) Synthetic procedure for compounds 6 and 7: $41.0 \mathrm{~g}$ (13.1 $\mu \mathrm{mol})$ and isobutylamine $95.9 \mathrm{mg}(1.3 \mathrm{mmol})$ were dissolved in $20 \mathrm{~mL}$ THF and stirred at RT for $2 \mathrm{~h}$, resulting in a colorless solution. The solution was poured into a large excess of hexane to precipitate an objective polymer. The polymer was further purified by a reprecipitation method from the THF/hexane system to give a pure thiol-terminated PMEA, 6, as a colorless viscous liquid ( $0.67 \mathrm{~g})$. Subsequently, $6100 \mathrm{mg}(1.31 \mu \mathrm{mol})$ was dissolved in $2 \mathrm{~L}$ of diethyl ether/THF $(\mathrm{v} / \mathrm{v}=3 / 1)$, and then iron (III) chloride $0.93 \mathrm{~g}$ (5.24 mmol) was added and stirred at RT for 1 month. The reaction mixture was concentrated in vacuo and poured into hexane to precipitate a resultant polymer as a yellowish viscous liquid. The polymer was passed through an alumina column using THF as an eluent. The solvents were removed in vacuo to obtain an objective cyclic PMEA, 7, as a colorless, viscous solid (38 mg). ${ }^{1} \mathrm{H}$ NMR [400 MHz, $\left.\mathrm{CDCl}_{3}, \mathrm{TMS}\right]$ (Figure S5): $\sigma=1.30-3.0 \mathrm{ppm}\left(-\left(\mathrm{CH}_{3}\right) \mathrm{CH}(=\mathrm{O}) \mathrm{OCCH}_{2}-\mathrm{CH}_{2} \mathrm{OC}\right.$ $(=\mathrm{O}) \mathrm{CH}\left(\mathrm{CH}_{3}\right)-, t, 6 \mathrm{H}$; PMEA, methylene (main chain), 2(1-xnH; PMEA, methine (main chain), $(1-x n \mathrm{H}), 3.26-3.47 \mathrm{ppm}(-\mathrm{CO}(=0)$ $\mathrm{CH}_{2} \mathrm{CH}_{2} \mathrm{OCH}_{3}, 3(1-x n \mathrm{H}), 3.48-3.70 \mathrm{ppm}\left(-\mathrm{CO}(=\mathrm{O}) \mathrm{CH}_{2} \mathrm{CH}_{2} \mathrm{OCH}_{3}\right.$, $2(1-x n \mathrm{H}), 4.00-4.47 \mathrm{ppm}\left(-\left(\mathrm{CH}_{3}\right) \mathrm{CH}(=\mathrm{O}) \mathrm{OCCH}_{2} \mathrm{CH}_{2} \mathrm{OC}(=\mathrm{O}) \mathrm{CH}-\right.$ $\left(\mathrm{CH}_{3}\right)-$, s, $4 \mathrm{H} ;-\mathrm{CO}(=\mathrm{O}) \mathrm{CH}_{2} \mathrm{CH}_{2} \mathrm{OCH}_{3}, 2(1-x n \mathrm{H}), 4.77 \mathrm{ppm}(-$ $\left.\left(\mathrm{CH}_{3}\right) \mathrm{CH}(=\mathrm{O}) \mathrm{OCCH}_{2} \mathrm{CH}_{2} \mathrm{O}-\mathrm{C}(=\mathrm{O}) \mathrm{CH}\left(\mathrm{CH}_{3}\right)_{-}, q, 2 \mathrm{H}\right)$. SEC [THF, 40 ${ }^{\circ} \mathrm{C}$, PSt standard] (Figure 2, violet): $M_{\mathrm{p}, \mathrm{L}}=88,200 \mathrm{~g} \mathrm{~mol}^{-1}, M_{\mathrm{p}}$, $\mathrm{c}=63,500 \mathrm{~g} \mathrm{~mol}^{-1}, Ð=1.27$.

(14) (a) Wang, Z.; He, J.; Tao, Y.; Yang, L.; Jiang, H.; Yang, Y. Macromolecules 2003, 36, 7446. (b) Llauro, M. F.; Loiseau, J.; Boisson, F.; Delolme, F.; Ladavière, C.; Claverie, J. J. Polym. Sci., Part A: Polym. Chem. 2004, 42, 5439. (c) Scales, C. W.; Convertine, A. J.; McCormick, C. L. Biomacromolecules 2006, 7, 1389.

(15) (a) Whittaker, M. R.; Goh, Y.-K.; Gemici, H.; Legge, T. M.; Perrier, S.; Monteiro, M. J. Macromolecules 2006, 39, 9028. (b) Laurent, B. A.; Grayson, S. M. Chem. Soc. Rev. 2009, 38, 2202. (c) Stamenović, M. M.; Espeel, P.; Baba, E.; Yamamoto, T.; Tezuka, Y.; Prez, F. E. D. Polym. Chem. 2013, 4, 184.

(16) (a) Roovers, J. E. L.; Toporowski, P. M. Macromolecules 1983, 16, 843. (b) Lepoittevin, B.; Dourges, M. A.; Masure, M.; Hemery, P.; Baran, K.; Cramail, K. Macromolecules 2000, 33, 8218. (c) Takano, A.; Kushida, Y.; Aoki, K.; Masuoka, K.; Hayashida, K.; Cho, D.; Kawaguchi, D.; Matsushita, Y. Macromolecules 2007, 40, 679. (d) Jeong, Y.; Jin, Y.; Chang, T. Macromolecules 2017, 50, 7770.

(17) (a) Clarson, S. J.; Semlyen, J. A. Polymer 1986, 27, 1633. (b) Yamamoto, T.; Tezuka, Y. Polym. Chem. 2011, 2, 1930. (c) Jia, Z.; Monteiro, M.J.J.Polym. Sci., Part A: Polym. Chem. 2012, 50, 2085.(d) Gao, L.; Oh, J.; Tu, Y.; Chang, T.; Li, C. Y. Polymer 2019, 170, 198.

(18) (a) Reimschuessel, H. K.; Turi, E. A.; Akkapeddi, M. K.J. Polym. Sci., A: Polym. Chem. 1979, 17, 2769. (b) Drake, A. C.; Lee, Y.; Burgess, E. M.; Karlsson, J. O. M.; Eroglu, A.; Higgins, A. Z. PLoS One 2018, 13, e0190713.

(19) (a) Magerl, D.; Philipp, M.; Qiu, X.-P.; Winnik, F. M.; MullerBuschbaum, P. Macromolecules 2015, 48, 3104. (b) Yan, W.; Divandari, M.; Rosenboom, J.-G.; Ramakrishna, S. N.; Trachsel, L.; Spencer, N. D.; Morgese, G.; Benetti, E. M. Polym. Chem. 2018, 9, 2580. 
(20) (a) Kittaka, S.; Ueda, Y.; Fujisaki, F.; Iiyama, T.; Yamaguchi, T. Phys. Chem. Chem. Phys. 2011, 13, 17222. (b) Cuadrado-Collados, C.; Majid, A. A. A.; Martínez-Escandell, M.; Daemen, L. L.; Missyul, A.; Koh, C.; Silvestre-Albero, J. Carbon 2020, 158, 346.

(21) (a)Zimm, B. H.; Stockmayer, W. H.J. Chem. Phys. 1949, 17, 1301.(b) Jang, S. S.; Cagin, T.; Goddard, W. A.J. Chem. Phys. 2003, 119, 1843. (c) Magerl, D.; Philipp, M.; Metwalli, E.; Gutftreund, P.; Qiu, X. P.; Winnik, F. M.; Muller-Buschbaum, P.ACS Macro Lett. 2015, 4, 1362.
(22) (a) Murakami, D.; Kobayashi, S.; Tanaka, M. ACS Biomater. Sci. Eng. 2016, 2, 2122. (b) Murakami, D.; Kitahara, Y.; Kobayashi, S.; Tanaka, M. ACS Biomater. Sci. Eng. 2018, 4, 1591. (c) Ueda, T.; Murakami, D.; Tanaka, M. Front. Chem. 2018, 6, 542. (d) Ueda, T.; Murakami, D.; Tanaka, M. Colloids Surf., B 2021, 199, 1115.

(23) Hirata, T.; Matsuno, H.; Kawaguchi, D.; Yamada, N. L.; Tanaka, M.; Tanaka, K. Phys. Chem. Chem. Phys. 2015, 17, 17399. 